\title{
Using Standard Digital Extra-Oral Photography in Patient With Cleft Lip and Palate
}

\author{
Uso de Fotografía Digital Extra Oral Estandarizada en Pacientes con Fisura Labiopalatina
}

Tatiana S. Paiva; Marcia Andre \& Beatriz Silva Camara-Mattos

PAIVA, T. S.; ANDRE, M. \& CAMARA-MATTOS, B. S. Using standard digital extra-oral photography in patient with cleft lip and palate. Int. J. Odontostomat., 13(3):345-349, 2019.

\begin{abstract}
A standardized photographic documentation is reproducible, which facilitates the evaluation of new techniques, treatment planning, and comparison of results. Clinical photography is important to impart scientific education to health professionals, because techniques can be better understood by the listener or reader when they are well illustrated. Documentation of consistent imaging of clinical diagnosis and treatment is also essential in medical-legal cases. Highquality clinical photographs along with radiographs and other medical and dental images should become an integral part of patients' medical records. Variables such as lens selection, camera position, distance, and patient's position should be understood and controlled by healthcare personnel for acquiring accurate photographs. In the case of patients with craniofacial deformities, such as cleft lip and palate, it is important to establish the standardization of photographic records because the patients' aesthetic evaluation is a fundamental clinical indicator in the deformity analysis, besides assisting the planning of patients' multidisciplinary treatment. This article aims to assist health professionals in acquiring standardized facial photographs (front, right profile, left profile, and submental oblique view) of patients with cleft lip and palate.
\end{abstract}

KEY WORDS: photography, standards, cleft lip, cleft palate.

\section{INTRODUCTION}

The craniofacial deformity and its rehabilitation must have a multidisciplinary approach. One of the main objectives of restorative surgeries is to restore pleasant facial aesthetics and consequently the acceptability of the individual in society (Paiva et al., 2014). Facial appearance is important for first impressions because an individual may face social challenges such as stereotyping (Salmória et al., 2014).

Standardized and high-quality photographic images are fundamental to assist in the planning of a surgical procedure, to explain a treatment plan to the patient, to be part of the clinical diagnosis documentation, and to assist in medical-legal cases. In addition, clinical photography is important to impart scientific education to health professionals, because the techniques can be better understood when well-illustrated. Photographs along with radiographs and other diagnostic reports should be a part of patients' records (Claman et al., 1990; Ettorre et al., 2006; Masioli et al., 2007).
Photographic standardization is the key to good medical photography. This applies to the background, lighting, enlargements, and positioning of the patient (IMI national guideline). In many cases health professionals do not have the knowledge or skill to take standardized biomedical photographs, resulting in images where comparisons before and after treatment do not present anatomical characteristic accuracy (Claman et al.; Ettorre et al.; Hexsel et al., 2017).

In the case of cleft lip and palate, which is the most frequent congenital craniofacial deformity, it is important to establish a standardization of photographic records because the aesthetic evaluation of the patient is an important clinical indicator in facial deformity analysis. In addition, these photographic records may help plan a patient's multidisciplinary treatment to enable doctors or specialists to compare results (Paiva \& Andre, 2012). 
This article aims to assist health professionals to acquire standardized photographs of patients with cleft lip and palate to assure more accurate photographs for a comparison of results, treatment planning, clinical records, and scientific teaching.

\section{MATERIAL AND METHOD}

Fifty five individuals with unilateral cleft lip and palate were selected for the follow up at the clinic of the Maxillofacial Prosthodontics Clinics of the University of São Paulo School of Dentistry. All patients selected, regardless of gender or race, did not present any abnormalities other than lip fissure or associated syndromic conditions.

Standard Digital Photos. For each patient it is recommended to perform four photographic shots: frontal, right profile, left profile, and submental oblique view (Fig. 1). For the standardization of photographic shots, it is important to abide by some necessary parameters such as digital camera adjustment, background color, lighting, and camera/patient distance. For this work, the photographic standardization recommendations by the Institute of Medical Illustrators were used (www.imi.org.uk) (Institute of Medical Illustrators, 2004).

Camera and lens. The standard equipment recommended is a digital SLR (Single Lens Reflex) camera, as it provides high quality images combined with the possibility of lens variation, adjustments in aperture settings, and shutter speed. This type of equipment, when well-adjusted and used with good technique, produces photographs with good focus, good depth of field, light, and color. Most digital cameras allow the placement of a grid that divides the viewfinder into three-thirds vertical and horizontal, facilitating the most precise and reproducible framing of the patient's face (Ettorre et al.; Swamy \& Most, 2010; Goodlin, 2011; Faccirolli \& Calixto, 2011).

For lenses, it is suggested to choose fixed focal length with macro $(100 \mathrm{~mm})$ lenses that show good performance for extra and intraoral photographs. High quality lenses ensure maximum depth of field, with less distortion and minimal color change. It is ideal that the pre- and post-operative images are taken with the same lens to avoid different focal lengths (Ettorre et al.; Swamy \& Most).

Recommended settings for extra-oral photographs are $f / 8$ or $f / 11$ aperture; exposure time $1 / 60,1 / 100$, or $1 / 125$; ISO 200 or 400 ; flash white balance; TTL flash with a +1 power; $100 \mathrm{~mm}$ objective; and manual mode lens (Yoshio \& Calixto, 2011; Yoshio, 2011).

Lighting and background. It is important to point out that the objective of medical-dental photography is technical and textual; therefore, it is not necessary to set up photographic studios with external flash and umbrellas. In extra-oral photographs it is possible to use ambient lighting, but for standardization, it is best to use flash with manual exposure mode (M). The preference is for built-in and pop-up flashes or external flashes. Good lighting results in facial contours with soft or absent shadows (Yoshio \& Calixto; Yoshio).
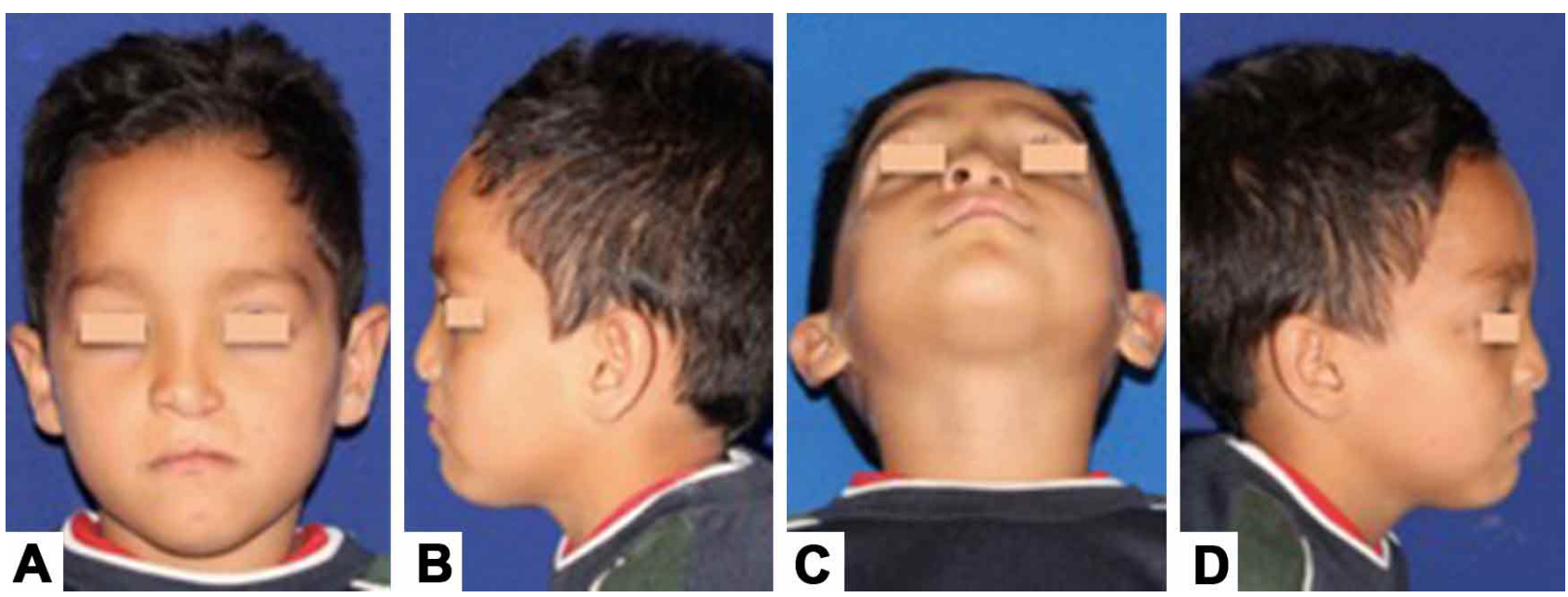

Fig. 1. Representative standardized photos taken of each patient. (a) Front view. (b) Left lateral view. (c) Submental oblique view. (d) Right lateral view. 
For built-in/pop-up flashes, in the front and submental oblique, the flash light should be above the objective (12 o'clock position). This provides soft, even shadows on the patient's face, which highlights the details. In the lateral photographs, the flash should be facing the patient's nose, creating an image with a nice contour so that the shadows are on the back of the patient's head (Masioli et al.).

The blue background is ideal for medical-dental photography as it provides good contrast for all skin colors, is pleasing to the viewer, softens possible shadows, and does not alter the color of the subject being photographed (Swamy \& Most).

Informed Consent Form. Documentation regarding consent for photographing must be obtained before taking any photographs. In case of minors, consent can be given by parents or legal guardians. The consent form should be easily understood and should not exceed one page. The patient should be informed that the images will become part of their medical-dental record and will be essential for treatment planning and follow-up. It should be clear that patient consent is voluntary, and denial of consent should not hamper clinical care. The information provided should be confidential and only known to the accountable researchers. The research subjects should not be identified at any time, even when research results are disclosed in any medium. Nevertheless, one must be aware that image use, especially in electronic publications, can reach a wider audience than standard medical texts and journals, and that the image placed in the public domain, even without identification, cannot be removed once it has been published
(Dysmorphology Subcommittee of the Clinical Practice Committee, American College of Medical Genetics, 2000).

Photographic preparation and positioning. Appropriate preparation for photographic documentation is essential to produce quality photographs that capture anatomical details and are reproducible. The patient's hair should be secured to expose the entire face, including the forehead and ears. Glasses, jewelry, and makeup should be removed.

The predetermined positions between the photographer and the patient are fundamental to obtain an image size pattern and proportion. For a $100 \mathrm{~mm}$ lens, the ideal distance for framing the face and shoulders' top is between 2.5 and $3 \mathrm{~m}$. If a tripod is used, placing fixed markers on the floor can be useful.

The camera height should be at the same level as the focus point; these will be mentioned in the descriptions of the respective shooting positions (Fig. 2). For the patient and the camera to maintain the same height, it is suggested to use a chair equipped with upright adjustment and a backrest. Because most of the focus points are aligned with the Frankfort horizontal line, this will reduce the need for height changes in each photographic shot.

Frontal photography. For the face's frontal photograph, the patient's head should be aligned with the Frankfort horizontal line. The focal point should be the intersection between the Frankfort horizontal line and the face's midline. The lower margin of the sternum-clavicular junction should be uncovered, and
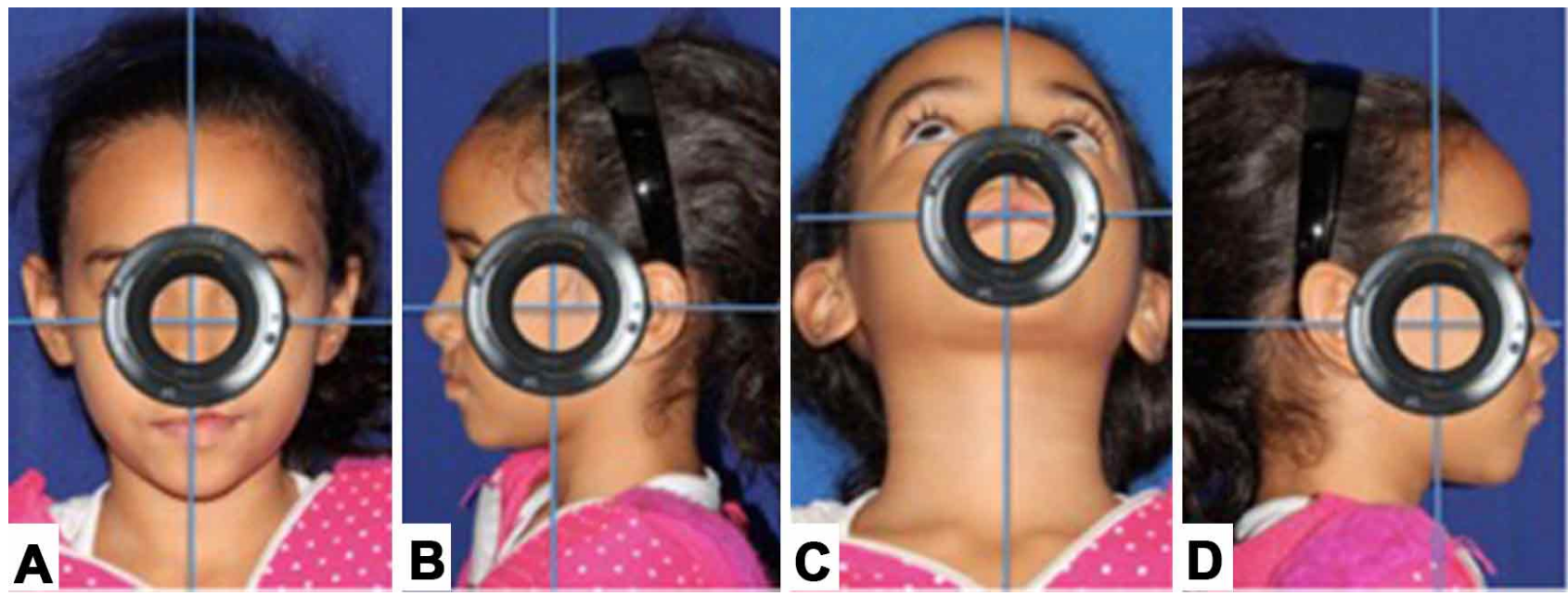

Fig. 2. Photographic camera height at the same level as the focal point on the frontal photograph (A), left profile photograph (B), submental oblique photograph (C), and right profile photograph (D). 
the background should be visible around the face. The lips should be relaxed and the interlabial line visible (Fig. 3).

Profile photography. In this photographic shot, the patient's head should be positioned similarly to the frontal view but rotated $90^{\circ}$ laterally. The contralateral eye should not be visible. The focal point should be the intersection between the Frankfort horizontal line and the midline between the tragus and the epicanthus of the ipsilateral eye. This view will also be composed of two images, one with relaxed lips and a visible interlabial line (Fig. \$A) and the other in maximum intercuspation (Fig. 4B).

Submental oblique view photography. For this type of photographic shot, the interpupillary line should be parallel to the horizontal axis with rotation of the occipitomental axis. The focal point and center of the photograph should be the intersection between the interlabial line and the midline of the columella (Fig. 5A).
A wooden stand can be supported on the chair's seat during this photographic shot with the objective of obtaining an average angulation of $45^{\circ}$ to the occipitomental axis. In this way, the face is inclined so as to expose the entire nasal base (Fig. 5B).

\section{CONCLUSIONS}

Photographs are essential tools for surgical preparation/planning, patient communication, clinical education, and medical jurisprudence. Deviations from standardization can lead to misleading results. Therefore, it is essential to standardize equipment, lighting, and patient positioning to obtain reproducible and high-quality photographs. Health progress and research are dependent on the exchange of experiences. This communication facilitates interdisciplinary discussion, making standardized photographs in clinical texts necessary for this process.

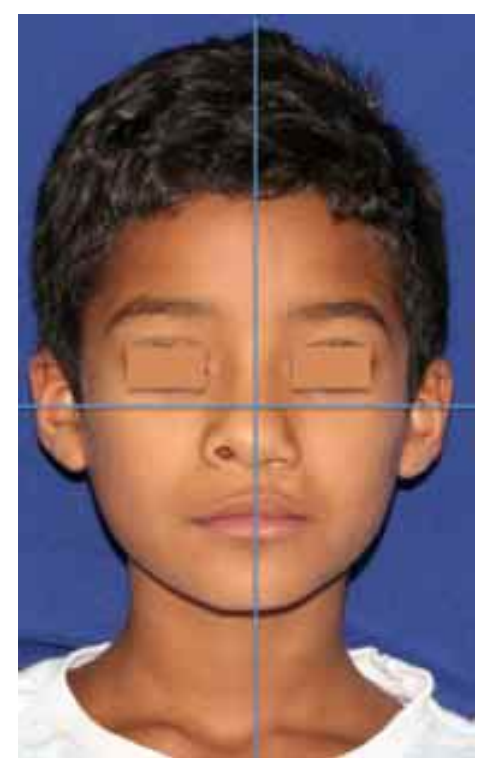

Fig. 3. Frontal photography.
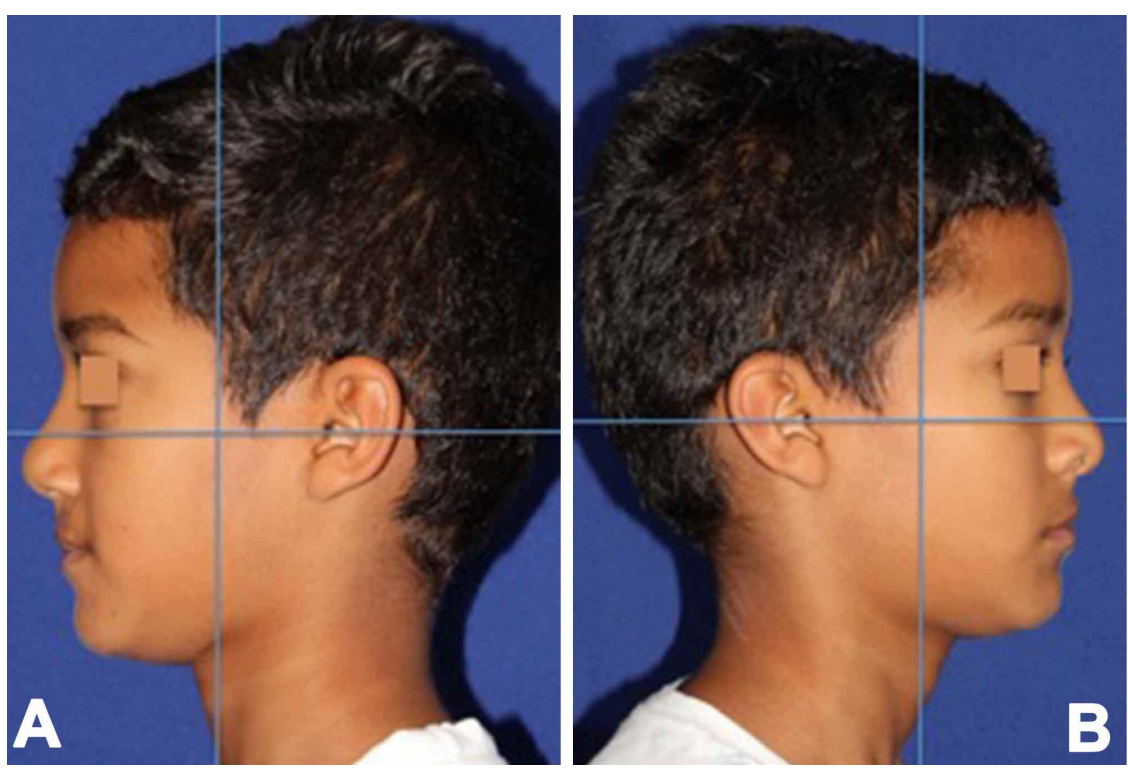

Fig. 4. A. Left profile photography. B. Right profile photography.
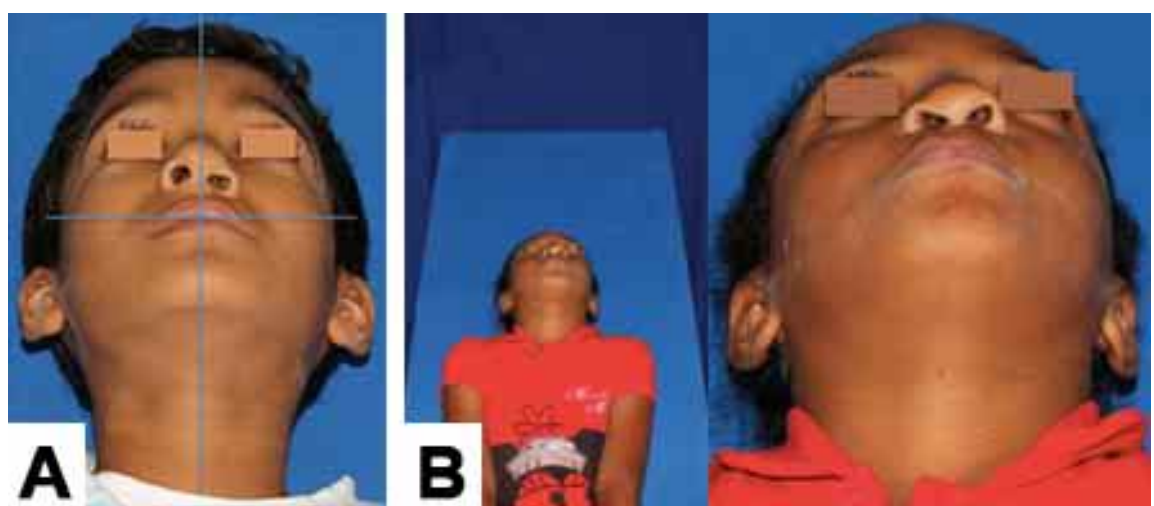

Fig. 5. A. Submental oblique photography. B. Head support for submental oblique photography. 
In patients with facial skull deformities, especially patients with great loss of maxilla, standardized photography is an essential tool for the improvement and refinement of techniques that benefit the patients and professionals who are directly involved.

PAIVA, T. S .; ANDRE, M. \& CAMARA-MATTOS, B. S. Uso de fotografía digital extraoral estandarizada en pacientes con fisura labiopalatina. Int. J. Odontostomat., 13(3):345-349, 2019.

RESUMEN: Una documentación fotográfica estandarizada es reproducible, lo que facilita la evaluación de nuevas técnicas, la planificación del tratamiento y la comparación de resultados. La fotografía clínica es importante para impartir educación científica a los profesionales de la salud, ya que el oyente o lector puede comprender mejor las técnicas cuando están bien ilustradas. La documentación de imágenes consistentes de diagnóstico clínico y tratamiento también es esencial en casos médico-legales. Las fotografías clínicas de alta calidad junto con las radiografías y otras imágenes médicas y dentales deben convertirse en una parte integral de los registros médicos de los pacientes. El personal de atención médica debe comprender y controlar las variables como la selección de la lente, la posición de la cámara, la distancia y la posición del paciente para obtener fotografías precisas. En el caso de pacientes con deformidades craneofaciales, como labio leporino y paladar hendido, es importante establecer la estandarización de los registros fotográficos porque la evaluación estética de los pacientes es un indicador clínico fundamental en el análisis de la deformidad, además de ayudar en la planificación del tratamiento multidisciplinario del paciente. Este artículo pretende ayudar a los profesionales de la salud a adquirir fotografías faciales estandarizadas (frente, perfil derecho, perfil izquierdo y vista oblicua submental) de pacientes con labio leporino y paladar hendido.

PALABRAS CLAVE: fotografía, normas, labio leporino, paladar hendido.

\section{REFERENCES}

Claman, L.; Patton, D. \& Rashid, R. Standardized portrait photography for dental patients. Am. J. Orthod. Dentofacial Orthop., 98(3):197-205, 1990.

Dysmorphology Subcommittee of the Clinical Practice Committee, American College of Medical Genetics. Informed consent for medical photographs. Dysmorphology Subcommittee of the Clinical Practice Committee, American College of Medical Genetics. Genet. Med., 2(6):353-5, 2000.

Ettorre, G.; Weber, M.; Schaaf, H.; Lowry, J. C.; Mommaerts, M. Y. \& Howaldt, H. P. Standards for digital photography in cranio-maxillofacial surgery - Part I: Basic views and guidelines. J. Craniomaxillofac. Surg., 34(2):65-73, 2006.
Goodlin R. Photographic-assisted diagnosis and treatment planning. Dent. Clin. North Am., 55(2):211-27, 2011.

Hexsel, D.; Hexsel, C. L.; Dal'Forno, T.; Schilling de Souza, J.; Silva, A. F. \& Siega, C. Standardized methods for photography in procedural dermatology using simple equipment. Int. J. Dermatol., 56(4):444-51, 2017.

Institute of Medical Illustrators. Photography of cleft audit patients. J. Audiov. Media Med., 27(4):170-4, 2004.

Masioli, M. A.; Masioli, D. L. C. \& Damázio, W. Q. Fotografia digital na clínica diária. In: $25^{\circ}$ Congresso Internacional de Odontologia de São Paulo, 27-31 jan. 2007. São Paulo, CIOSP, 2007.

Paiva, T. S. \& Andre, M. Evaluating aesthetics of the nasolabial region in children with cleft lip and palate: professional analysis and patient satisfaction. Patient Prefer. Adherence, 6:781-7, 2012.

Paiva, T. S.; Andre, M.; Paiva, W. S. \& Mattos, B. S. C. Aesthetic evaluation of the nasolabial region in children with unilateral cleft lip and palate comparing expert versus nonexperience health professionals. Biomed Res. Int., 2014:460106, 2014.

Salmória, I.; Furtado, A.; Rosário, H. D.; Furtado, G. C. \& Paranhos, L.R. Análise facial de Arnett e Bergman comparada a percepção estética de leigos e cirurgiões-dentistas (clínicos gerais e ortodontistas). Biosci. J., 30(1):297-303, 2014.

Swamy, R. S. \& Most, S. P. Pre- and postoperative portrait photography: standardized photos for various procedures. Facial Plast. Surg. Clin. North Am., 18(2):245-52, 2010.

Yoshio, I. \& Calixto, L. R. Fotografia de face na odontologia. Rev. Dent. Press Estét., 8(2):34-44, 2011.

Yoshio, I. Fotografia intrabucal envolvendo dentes anteriores: flash twin. Rev. Dent. Press Estét., 7(4):31-7, 2010.

Corresponding author:

Tatiana Saito Paiva DDS

306 Mato Grosso Street, Office 1301

Zipcode 01239-040

São Paulo

BRAZIL

Email tatianasaito@usp.br

Recibido : 30-04-2019

Aceptado: 23-05-2019 